\title{
The Effect of Mg Supplement on Hydroxyapatite Produced by Chemical Precipitation
}

\author{
F.E. BAşTAN*, G. AĞTAŞ, Y.Y. ÖZBEK AND F. Üstel \\ Sakarya University, Engineering Faculty, Department of Metallurgical and Metarials Engineering \\ 54187, Esentepe Campus, Sakarya, Turkey
}

\begin{abstract}
Hydroxyapatite (HAp) exhibits excellent biocompatibility but the low mechanical strength of normal HAp ceramics generally restricts its use to low load-bearing applications. Magnesium is an attractive material for use in biodegradable implants due to its low density, non-toxicity and mechanical properties similar to those of human tissue such as bone. Its biocompatibility makes it amenable for use in a wide range of applications from bone to cardiovascular implants. The aim of this work was to produce hydroxyapatite powder with chemical precipitation method and supplement $\mathrm{Mg}$ and investigate the effect of magnesium on structure of HAp powders. The Mg content ranged between 1 and 2 mol.\%. The $\mathrm{Mg}+\mathrm{HAp}$ powders were examined for morphology. The scanning electron microscopy, X-ray diffraction, energy-dispersive X-ray spectroscopy were used to characterize the specimen powders.
\end{abstract}

DOI: 10.12693/APhysPolA.125.391

PACS: 81.20.Ev, 61.43.Gt, 87.85.J-

\section{Introduction}

HAp is the main mineral component of bones and teeth [1]. With the precipitation, sol-gel, hydrothermal synthesis methods, hydroxyapatite can be produced synthetically. However, synthetic hydroxyapatite has a similar composition to inorganic component of bone [2], natural hydroxyapatite has extra compounds like magnesium oxide, sodium oxide etc. Hydroxyapatite is used for dental and surgery applications with its high biocompatibility effects. Due to the poor mechanical properties of hydroxyapatite [3], it can be used with metallic-based implants like coating. Hydroxyapatite, on implantation, allows good bone ingrowth and eventually is replaced by endogenous bone [4]. Magnesium comprises $0.5 \%$ to $1 \%$ of bone ash and it is an important component of the hydroxyapatite lattice. Magnesium can also directly influence on hydroxyapatite crystal formation and growth [5]. Magnesium is an important bivalent ion associated to biological apatites [6].

\section{Experimental procedures}

Pure and $\mathrm{Mg}$ substituted HAp were produced with chemical precipitation method [7]. $\mathrm{Ca}\left(\mathrm{NO}_{3}\right)_{2} \cdot 4 \mathrm{H}_{2} \mathrm{O}$ (Merck, 98\%), $\mathrm{H}_{3} \mathrm{PO}_{4}$ (Merck, $85 \%$ ), $\mathrm{Mg}\left(\mathrm{NO}_{3}\right)_{2} \cdot 6 \mathrm{H}_{2} \mathrm{O}$ (Merck, 99.99\%) were used for $\mathrm{Mg}$ substituted HAp synthesis and $\mathrm{NH}_{4} \mathrm{OH}$ were used for $\mathrm{pH}$ adjustment. $\mathrm{Ca}\left(\mathrm{NO}_{3}\right)_{2} \cdot 4 \mathrm{H}_{2} \mathrm{O}, \mathrm{H}_{3} \mathrm{PO}_{4}, \mathrm{Mg}\left(\mathrm{NO}_{3}\right)_{2} \cdot 6 \mathrm{H}_{2} \mathrm{O}$ were dissolved in deionized water separately and $\mathrm{NH}_{4} \mathrm{OH}$ was added to all of the solutions to increase the $\mathrm{pH}$ level to 10-11. Then magnesium nitrate solution was added into

*corresponding author; e-mail: febastan@sakarya.edu.tr calcium nitrate solution which was continuously stirred by magnetic stirrer. After a while later, finally, orthophosphoric acid solution was added slowly. Final $\mathrm{pH}$ level was measured as about 10. Liu pointed out that increasing $\mathrm{pH}$ brought about low crystallinity $[8]$ which stands for nanostructure. With adding orthophosphoric acid solution, simultaneously, gelatinous solution was produced. After the solution was stirred for $24 \mathrm{~h}$ at room temperature, hydroxyapatite particles were precipitated for $24 \mathrm{~h}$. Then the solution was filtered with adding deionized water to remove remaining residuals. Finally wet product was dried in the furnace at $105^{\circ} \mathrm{C}$ for $24 \mathrm{~h}$. After drying product was grinded with agate mortar.

For characterization, scanning electron microscopy (SEM) (TESCAN VEGA II) was performed to investigate the microstructure of powders, X-ray diffraction (XRD) (RIGAKU D/MAX/2200/PC) was performed to identify phases in the structure, energy dipersive X-ray spectroscopy (EDX) analyses (BRUKER Quantax) were performed for elemental analysis, particle size analyses (MICROTRAC S3500) were performed.

\section{Results and discussions}

SEM micrographs and EDX analyses results were shown in Fig. 1. It was obvious that particles had sharp-edged shape because of grinding with agate mortar.

With EDX analysis, it can be seen in Fig. 2 that there were $\mathrm{Mg}$ elements in 1, 2 mol.\% Mg substituted HAp. Mg content was added succesfully to HAp structure. The other elements were the same, calcium, phosphate and oxygen which were in HAp structure.

Chaudhry investigated that adding 1 to 2 wt\% $\mathrm{Mg}$ contents to hydroxyapatite structure led to biphasic calcium-phosphate mixtures as hydroxapatite-Mg whitlockite [9]. Similar situation was shown in Fig. 3. 


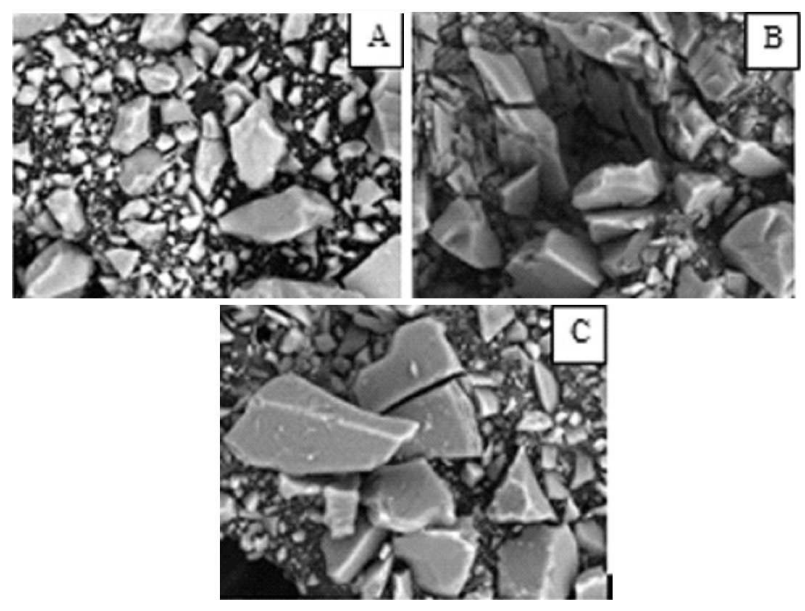

Fig. 1. SEM micrographs of hydroxyapatite particles: (a) pure HAp, (b) 1 mol.\% $\mathrm{Mg}$ substituted HAp, (c) 2 mol.\% Mg substituted HAp.

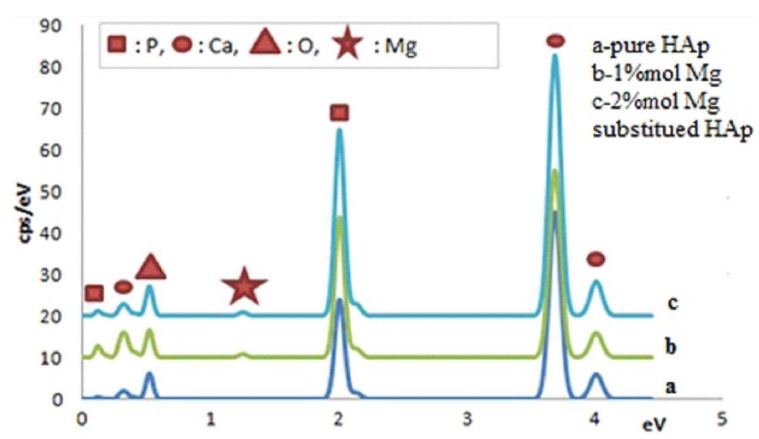

Fig. 2. EDX analysis results: (a) pure HAp, (b) 1 mol.\% Mg substituted HAp, (c) 2 mol.\% Mg substituted HAp.

It is shown in Fig. 4 that $1 \% \mathrm{Mg}$ substituted HAp peak fit into $2 \% \mathrm{Mg}$ substituted HAp peak. Particle size was connected with grinding. Whole particle size ranges between 1 to $700 \mu \mathrm{m}$.

\section{Conclusion}

In this study, the effect of magnesium supplement was investigated. High crystallinity was provided after sin-

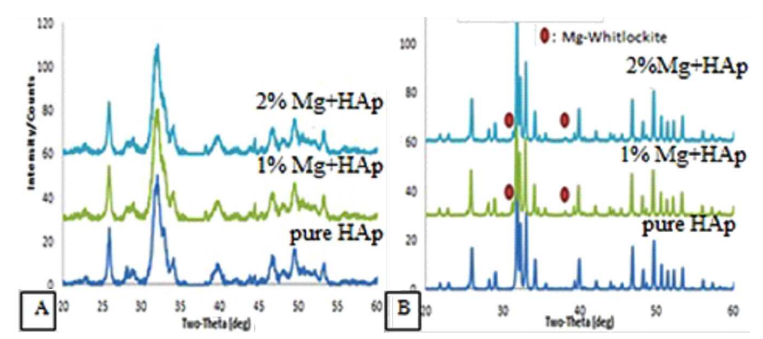

Fig. 3. XRD patterns: (A) before sintering, (B) after sintering at $900^{\circ} \mathrm{C} / 1 \mathrm{~h}$ at air atmosphere.

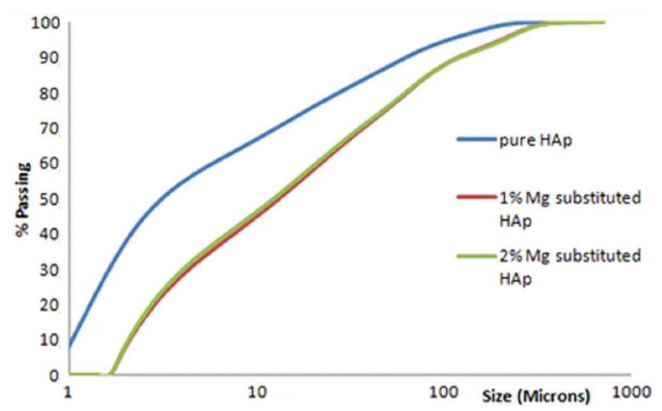

Fig. 4. The results of particle size analysis.

tering hydroxyapatite. It was shown that magnesium addition in hydroxyapatite led to biphasic mixture of hydroxyapatite and Mg-whitlockite in XRD results. Magnesium, silver, and some other cations can be added with chemical precipitation to hydroxyapatite structure easily. SEM results showed that microstructures were sharp-edged because of grinding.

\section{Acknowledgments}

Some of these investigations were studied (SEM, particle size analysis) at Sakarya University Thermal Spray Research and Development Laboratory.

\section{References}

[1] M. Enayati-Jazi, M. Solati-Hashjin, A. Nemati, F. Bakhshi, Superlatt. Microstruct. 51, 877 (2012).

[2] C. Ergun, J. Mater. Proc. Technol. 199, 178 (2008).

[3] M. Zhang, C. Liu, J. Sun, X. Zhang, Ceram. Int. 37, 2025 (2011).

[4] W.G. Billotte, in: The Biomedical Engineering Handbook, Ed.: J.D. Bronzino, 2nd ed., Vol. 2, CRC Press, Boca Raton 2000.

[5] R.K. Rude, in: Principles of Bone Biology, 3rd ed., Eds. J.P. Bilezikian, L.G. Raisz, T.J. Martin, Academic Press, 2008, p. 487.

[6] E. Bertoni, A. Bigi, G. Cojazzi, M. Gandolfi, S. Panzavolta, N. Roveri, J. Inorg. Biochem. 72, 29 (1998).

[7] F.E. Bastan, Y.Y. Ozbek, Materiali in Tehnologije 47, 431 (2013) (in Turkish).

[8] J. Liu, X. Ye, H. Wang, M. Zhu, B. Wang, H. Yan, Ceram. Int. 29, 629 (2003).

[9] A.A. Chaudhry, J. Goodall, M. Vickers, J.K. Cockcroft, I. Rehman, J.C. Knowles, J.A. Darr, J. Mater. Chem. 18, 5900 (2008). 